\section{ICRO Struggles On}

The International Cell Research Organization is one of the many pensioners of Unesco which are at present finding it difficult to finance their aspirations. ICRO is in fact so short of money that in the past two years its activities have appreciably declined. Worse still, the outlook for the next two years is not all that encouraging. Unesco has proposed a budget of $\$ 105,000$ for $1969-70$, little more than a 5 per cent increase over the past two years. On the other hand, Unesco, for the time being at least, seems prepared to support the organization beyond 1972, which had originally been the deadline.

What are ICRO's aims? It was set up in 1962, on the initiative of Unesco rather than of the scientific community, as a channel of international communication between cell biologists, with the general aim of promoting and even coordinating cell biology research and teaching and also of advising Unesco in the field. This has boiled down to the organization of training courses, which have been very successful so far and which account for two-thirds of the organization's budget: the provision of a limited fellowship programme intended to supplement existing fellowship schemes in various ways (for example, by providing travel costs and helping with family commitments); the drawing up of a world directory of cell research laboratories, which is bound to be out of date by the time it is published; and the setting up of research panels. The panels, dealing with specific topics, have the job of organizing the training courses and of drawing up or, if possible, initiating research programmes in their fields.

Nowadays international researeh organizations and unions are the vogue, and it is a sign of the times that the ICRO associates in its work with no fewer than nine international unions interested in eell biology. At first ICRO seemed to fulfil a genuine need, and between 1963 and 1966 there were plenty of signs that its activities were really beginning to flourish. In the past two years, however, the organization seems to have suffered something of an eclipse. Thus in 1965-66 it awarded 35 fellowships, while in the past two years only 27 have been given. In 1965-66 it organized ten training courses, but in the past two years only five have been held, and of the eight working panels that have been set up only one managed to hold a formal meeting in the two years. Some panels have never formally met. To be sure, the members of the panels do keep in touch with cach other and with the secretariat by correspondence, but their failure to meet suggests that the panel members are not all white-hot propagandists for the aims of the ICRO.

But the really significant pointer is the decline, during the past two years, in the number of training courses. Modelled along the lines of those held at Cold Spring Harbor, the TCRO courses rapidly established themselves as being of the highest scientific standing. The fierce competition for the limited number of places (the record was 248 applicants for a course with 16 places) is the surest index of their success and value. So far, some 400 scientists from 39 countries have attended the 24 ICRO courses, which have provided unique opportunities for the rapid dissemination of the most advanced techniques in the ficlds. ICRO is the only organization which attempts this on a fully international scale. Despite the overwhelming demand for the courses, however, ICRO seems not to have capitalized on their success. Apart from changes in its secretariat, there seem to be three reasons. First, the organization's budget has been frozen. One of the courses scheduled for this year, for example, was cancelled because the only available co-sponsor was the North Atlantic Treaty Organization, and political objections to a NATO-Unesco link were allowed to prevail even though another $1 \mathrm{CRO}$ course, which has been held for the past four years in Naples, has now been completely taken over by NATO and as a result receives twice as much money. ICRO clearly has to tread very delicately between conflicting international political interests and jealousies which saddle it with an extra handicap when it comes to fund raising.

Secondly, the cost of courses is increasing, and there is more competition in the summer school business. NATO, EMBO and FEBS, for example, all run their own courses, competing for both staff and venues. There is, in addition, a general trend in ICRO to transfer more of its activities to developing countries, with inevitable increases in costs. This last factor, of course, introduces the general problem of whether ICRO should encourage devcloping countries to devote a significant part of their meagre resources to promoting basic research which has no foresecable relevance to their economic development. Whatever goes on behind the scenes, the organization is inevitably unable to take a public stand on the issue. Its policy, so far as it has one, seems to be to give increasing priority to training courses in developing countries in fields which have some economic potential-applied microbiology, plant geneties and so on-without promoting second class or cheap scicnce.

Clearly if ICRO is to fulfil its great potential it will have to find new sources of politically acceptable money. In the past, the $\$ 8,000$ or so which ICRO has put up for a course has usually stimulated the host institution or country to give supplementary funds in exchange for more than its fair share of the places on the course, but this is not enough. The best prospects for new support seem to be other international agencies-WH() and the IAFA, for example-and private foundations. An attempt to obtain funds from the IAEA for the course which NATO would have financed failed because the IAEA was organizing its own symposia and possibly training courses. But the ICRO panel on the biology of fertility and reproduction is soliciting aid from WHO, and the Gulbenkian Foundation has agreed to finance a course in Portugal, although in this case ICRO already has the money. If this foundation is prepared to finance another ICRO course outside Portugal, and if WHO finances two courses on immunology, as is hoped, the organization may achieve its target of twelve training courses in the next two years. Then the 1970.ICRO council meeting would have more to congratulate itself on than did the last one in Paris in September. 